\title{
TOWARDS BREAKING THE BARRIERS FOR WOMEN'S INCLUSION IN CONFLICT RESOLUTION FOR SUSTAINABLE PEACE AND DEVELOPMENT IN NIGERIA
}

\author{
${ }^{1}$ PROF. HUSSAINATU ABDULLAHI (MRS); ${ }^{2}$ A.A.BELLO (Ph.D) \\ ${ }^{1}$ DEPARTMENT OF ECONOMICS, FACULTY OF SOCIAL SCIENCES, \\ USMANU DANFODIYO UNIVERSITY, SOKOTO, NIGERIA \\ ${ }^{2}$ FACULTY OF SOCIAL SCIENCES, DEPARTMENT OF ECONOMICS, \\ USMANU DANFODIYO UNIVERSITY, SOKOTO
}

DOI: 10.46609/IJSSER.2020.v05i05.011 URL:https://doi.org/10.46609/IJSSER.2020.v05i05.011

\section{ABSTRACT}

Women's role in socio-political and economic development through the reinforcement of their capacity and the need for their inclusion in all societal endeavours have been well documented in both National, Regional and International Instruments on Human Rights such as the (Nigeria's 1999 Constitution, NEPAD Document, Paragraph 49; and the United Nations Document on Human Rights). The global community has over the years accepted the need for a paradigm shift with respect to Women's inclusion in conflict resolution thus, Nigeria as a sovereign nation cannot be an isolated entity in the new narratives through the interrogation of the democratically Male controlled society, characterized by difficult emotional complexity, as well as the domineering ideology of relations at the family level, school, religious institutions and the work place. Therefore, the need for Women's inclusion in conflict resolution processes has not only become fundamental, but very crucial and urgent. This is occasioned by the fact that the consequences of conflict weigh more heavily on the female gender. Arising from the above, this paper utilizing qualitative analysis through archival and content sources of information examines development policies and gender approach to conflict resolution as well as the roles of Women in conflict situations and the barriers against their inclusion in the process of its resolution. The paper concludes by noting among others that for sustainable peace and development to be actualized in Nigeria, breaking the barriers on Women's inclusion in conflict resolution must be anchored on those challenges that inhibit their self actualization through prioritizing their rights in the area of education, training of Women negotiators and lobbyists, as well as treaty implementation and sensitization across the three tiers of government in Nigeria. 


\section{International Journal of Social Science and Economic Research}

ISSN: $2455-8834$

Volume: 05, Issue: 05 "May 2020"

Keywords: Barrier; Inclusion; Conflict Resolution; Peace; Sustainable Development.

\subsection{INTRODUCTION}

Persistent conflicts have dotted the history of Nigeria with about $80 \%$ of Women and children being victims (AbdulKarim, 2003). In the traditional society, Nigerian Women have played informal roles in conflict resolutions within immediate families, environment and social groups, while in formal peace building initiatives, they are never utilized at the dialogue table, largely due to gender stereotyping that Women lack the necessary attributes for conflict resolution and peace intervention (Abdullahi, 2014). As a result of the non-inclusion of Women at the conflict resolution initiatives, the country has remained in violent conflicts and not able to fashion out a holistic strategy for sustainable peace and development.

It is useful to quickly agree with Dunmoye (2014) who opines that the contemporary Nigeria's political economy is characterized by socio-economic and political instability, regional, religious and ethnic interest-based-conflicts, orchestrated by geo-political antagonisms, official kleptomania as well as unabated corruption which has remained a pathological psychology that has engulfed the ruling elites, as well as ad-hoc policy somersaults which has neglected resource generation in favour of distribution. Consequently, the Nigerian nation is faced with a tripartite and mutually reinforcing conflicts of development, legitimacy and security.

Thus, living in a democratically Male controlled society, characterized by difficult emotional complexity, as well as the domineering ideology in all ramifications of relations, such as the family, school, religious institutions and the work place, the need for Women's inclusion in conflict resolution initiatives has become an imperative, because the consequences of conflict weigh more heavily on the Female gender. Indeed, Women's role in peace initiatives, sociopolitical and economic development through the reinforcement of their capacity and the need for their inclusion in all societal endeavours have been well documented in both National, Regional and International Instruments on Human Rights such as the (Nigeria's 1999 Constitution, NEPAD Document, Paragraph 49; and the United Nations Document on Human Rights). The global community no doubt has accepted a paradigm shift with respect to Women's inclusion in conflict resolution, thus, Nigeria cannot be an island in the new narrative by interrogating the need to break the barriers inhibiting the roles that Women could play towards achieving a fair and just society, as well as a social relation that will transform Nigeria's vision of actualizing lasting peace and sustainable development.

Indeed, the necessity for Women's inclusion in the process of conflict resolution is best elucidated using Emile Durkheim's (1917) Functionalist notion where he observes that the society is a system of interrelated components and if it is balanced, it will create smooth 
International Journal of Social Science and Economic Research

ISSN: $2455-8834$

Volume: 05, Issue: 05 "May 2020"

operation for overall social cohesion. Thus, the Functionalist ideology therefore, shows that when Women are included in any societal initiatives or processes, such action will lead to sustainable peace and development through conflict prevention, hence societal solidarity in all ramifications.

Arising from the above, we have utilized the qualitative method through archival and content analysis sources of information for this paper. Thus, the paper is structured into six (6) sections including this brief introduction as section one (1). Section two (2) is devoted to conceptual clarifications, Development Policies and Gender Approach to Conflict Resolution, while section three (3) examines the roles of Women in Conflict situations. Section four (4) is devoted to the discussion of the barriers against Women's inclusion in conflict resolution in Nigeria, while section five (5) examines the ways towards breaking the barriers for Women's inclusion in conflict resolution for sustainable peace and development in Nigeria. Section six (6) concludes the paper.

\subsection{CONCEPTS, DEVELOPMENT POLICIES AND GENDER APPROACH TO CONFLICT RESOLUTION}

In this section, some conceptual issues are discussed in addition to the influence of development policies in the evolution of gender approach to conflict resolution generally.

(a). Conceptual Clarifications: Here we have tried to provide brief clarifications of the following concepts: Barrier; Inclusion; Conflict Resolution; Peace; Sustainable Development.

(i). Barrier: This can be defined as "a material formation or structure like wall that prevents access or passage"; "Something immaterial that obstructs or impedes"; "a coordinated series of obstacles designed or employed to channel, direct, restrict, delay or stop the movement of an opposing force. Barriers can exist naturally or man-made or a combination of both"; Barrier is "something that causes difficulty towards success actualization"; "A problem that prevents two people or groups from agreeing, communicating, or working with each other"; "A rule, law or policy that makes it difficult for something to happen or be achieved". (https://www.thefreedictionary.com/barrier; https://www.collinsdictionary.com/dictionary/english/barrier).

(ii). Inclusion: This is defined as "the act of including someone or something as part of a group, list, etc, or a person or thing that is included"; "The idea that everyone should be able to take........part in the same activities, and enjoy the same experience". Inclusion "is a universal human right whose aim is to embrace all people irrespective of race, gender, disability, medical or other needs. It is about giving equal access and opportunities and getting rid of discrimination and intolerance (removal of barriers). It affects all aspects of public life". Inclusion may also 


\section{International Journal of Social Science and Economic Research}

ISSN: $2455-8834$

Volume: 05, Issue: 05 "May 2020"

mean/related to "involvement, incorporation, formation, admittance, embodiment, insertion, embracement, composition, subsumption, encompassment or comprisal". (https://dictionary.cambridge.org/dictionary/english/inclusion;.

https://www.dictionary.com/browse/inclusion;

www.inclusion.me.uk/news/what_does_inclusion_mean).

(iii). Conflict: General consensus among scholars connotes that conflict is a natural, normal and inevitable phenomenon in human relations which is not restricted to any specific level of human relations since it can occur among family members, at the community level, at both national and international levels (Abdullahi, 2014; Burton 1987; Weeks 1992; Galtung and Jacobsen 2000). According to Abdullahi (2014), conflict and peace are incompatible because they relate negatively. When conflict occurs, peace becomes a herculean task to attain. Therefore, peace requires transforming conflictual relationships into a harmonious one in order to eliminate the destructive effects of conflict.

Conflicts exist when struggle occur between two or more opposing forces, either over resources, values, ideas, wishes or deep-seated needs (Abdullahi, 2014). According to Imobighe (2004:17), "the term conflict represents a disharmony, antagonism or hostility in a relationship, which could arise due to incompatibility of the goals being pursued or incompatibility of the means used in pursuing the goals". Conflict can thus "be seen as a product of a clash of interests between those involved in some form of relationship".

(iv). Conflict Resolution: This is defined as the method or process involved in facilitating the peaceful ending of conflict and retribution. Committed group members try to resolve group conflicts through communication of information about their conflict ideologies to the rest of the group (e.g. intentions or reasons) for certain belief system by engaging in collective negotiation. The term 'Conflict Resolution' can also be used interchangeably with 'Dispute Resolution' involving arbitration and litigation process. Conflict Resolution can also encompass the adoption of non-violent resistance measures by the conflicted parties towards promoting effective resolution. There are some fundamental strategies for Conflict Resolution as different conflict scenario may require different methods or solution. These include:

- Reaching agreement on rules and procedures like meeting place and agenda setting.

- Reducing tension and synchronizing the de-escalation of hostility especially where emotions are high.

- Improving the communication method for understanding each other's perception.

- Controlling the number and size of issues to be discussed.

- Establishing common ground where parties can find a basis for agreement.

- Enhancing the desirability of the options and alternatives presented by each party. 


\section{International Journal of Social Science and Economic Research}

ISSN: $2455-8834$

Volume: 05, Issue: 05 "May 2020"

(v). Peace: According to Bello, Abdullahi and Olarinde (2016), "all human beings have a meeting point in language", thus the Oxford Dictionary defined "peace as the freedom from and the threat of war"; and "civil disorder". Civil disorder means rebellion against just, balanced, honest and decent government. "Peace means to have tranquillity, mental calm and safety within the borders of one's nation, the home and one's heart". On the other hand, the Dictionary of Modern English defined peace as a "state of harmony between people and groups; law and order throughout the State and the world; the absence of mental anxiety or psychological stress".

From these definitions, it is obvious that none has provided a clear and comprehensive definitions as applied to the moral and spiritual aspects of human existence, hence, the entire world has remained on the precipice of war and the possibility of annihilation of humanity, while those who have brought humanity to this abysmal level have no solution for peace to reign in the world (Bello, Abdullahi and Olarinde, 2016).

Therefore, it is useful to take a broader definition of "Peace" that encompasses not only the above, but goes further to address the very source of "Peace" itself. From the perspective of Arabic language, which is very rich in its meanings, the definition of the word "Peace or Islam" means "submission and surrender". It does not mean submission or surrender to any man-made legislation or conforming to any particular government. It means submission and surrender to the "Ultimate Creator" Who is the source of all existence, the Owner of human beings, Who is the Designer of the Heavens and Earth and Whom without His Benefits and without what He has sustained or given, the human beings themselves will not exist (Bello, Abdullahi and Olarinde, 2016).

According to Bello, Abdullahi and Olarinde (2016), the Holy Qur'an which is the highest and purest source of Arabic language has further qualified that such submission and surrender should be directed exclusively to the Uncreated Creator as well as the legislation which that Uncreated Creator has provided for the human race. Islamic Scholars have also provided a very clear definition of "Peace" in the following statement: "That Islam is Peace and submission to Almighty God; It means surrender, conforming and submission to Almighty God, the Uncreated Creator according to the rules which He has ordered His Messengers (Prophets) (ibid).

(vi). Sustainable Development: The World Commission on Environment and Development (WCED) (1987: 43), defined "sustainable development as development that meets the needs of the present generation without compromising the ability of the future generations to meet their own needs". This definition of sustainable development emphasizes two (2) basic issues, i.e. 'needs' and 'essential needs' of the world's poor to which overriding priority should be focused. Sustainable development thus, emphasizes that development should lead to: Poverty eradication (with people participating in decision making that affect their lives); Job creation and sustainable 
International Journal of Social Science and Economic Research

ISSN: $2455-8834$

Volume: 05, Issue: 05 "May 2020"

livelihood; Women empowerment and effective participation; and Environmental Protection. In other words, sustainable development promotes development which is: Pro-poor; pro-job; prowomen; and pro-environment (UNDP/NPC, 1997).

In the section that follows, we examine the role(s) of Women in conflict situations, as well as development policies and the evolution of gender approach to peace building.

\subsection{THE ROLE(S) OF WOMEN IN CONFLICT SITUATIONS, DEVELOPMENT POLICIES AND THE EVOLUTION OF GENDER APPROACH TO PEACE BUILDING}

\section{(a). The Role of Women in Conflict Situations:}

There is a general perception that when compared to the Male gender, Women are more naturally peaceful because, given their features, they are more gentle as a result of their maternal nurturing disposition when gauged against their Male counterparts who have very high propensity for belligerence and violence. Thus, while Men resort to aggressive method of resolving conflict situations physically, Women resort to subtle method of dialogue towards amicable resolution of their problems, thus the stereotyping of the Female gender as weak. Thus, Women are better disposed at sustaining peace, hence their roles in conflict situation and resolution remains fundamental.

Although, there is no doubt that modern-day armed conflict situation is horrific for Women. However, deep and entrenched patriarchal value system which has continued to relegate Women as second fiddle citizens has blatantly undervalued their contributions by ignoring their central and fundamental roles in conflict resolution and mediation processes. Nevertheless, conflict and post-conflict periods in recent times have provided women with new platforms and opportunities to bring about change. Consequently, the roles that Women undertake during conflict scenarios have continued to alter and expand as they participate in the struggles, by undertaking more economic responsibilities and duties as heads of households. The traumatic experience of the conflict also provides opportunities for Women to organize themselves towards a common agenda. This paradigm shift have led Women to become Activists, thus advocating for peace and long-term transformation in their respective communities, societies and the nation at large.

Over the years, Women have embraced the opportunities available for them to drive this advocacy to the next level through the establishment of an International Framework on Women, Peace, and Security. This efforts has attracted the United Nations Security Council through their Resolution 1325, as well as other International Agreements and Commitments towards Women's inclusion in post-conflict resolution and peace-building. It is useful to note that the participation of both gender (Women and Men) in a transparent and wholesome manner is highly essential towards preventing violent conflict and its resolution (Norlander, 2012). The roles that Women 


\section{International Journal of Social Science and Economic Research}

ISSN: $2455-8834$

Volume: 05, Issue: 05 "May 2020"

undertake during conflict scenarios include, but not limited to the following as such roles do vary in every conflict:

- They act as Agents for Positive change.

- They are active Participants as combatants (Female Armed Forces in all arms of Military such as Army, Navy or Air Force, Police, Civil Defence), etc.

- They act as voluntary or forced participants in providing services such as forced labour providers, War Camp Cooks, Slaves, Wives, general care givers, etc.

Thus, arising from the above, the opportunities to address the role of women in conflict scenarios is often misplaced due to the fact that fundamental issues are not usually understood, hence acknowledged. This therefore, calls for the need for Women to be included not only in conflict resolution, but also its prevention in the first instance as well as its management efforts at all strata. This is because, when they are not included as active participants, their views, felt-needs and the interests of the better half of the population are unrepresented, consequently intervention measures will not be provided adequately or appropriately or enduring. It is useful to note that since the consequences of war weigh more heavily on the lives of Women, it is only natural that they show honest interest in peace and peace-building processes. In most cases, peace itself is usually achieved very late due to non-inclusion of Women in the conflict resolution process. For instance the roles and diligence of Women as leaders of human rights organizations has been fundamental in creating international community awareness of the continuing conflicts around the globe, especially in Chechnya and Russia as well as in other African Countries.

\section{(b). Development Policies and the Evolution of Gender Approach to Peacebuilding:}

At the global level for instance, peacebuilding programs and policies have been in existence from the mid 1970s, which represented a paradigm shift in international development thoughts whereby "the meaning and role of gender and gender relations in development led to the awareness of change from Women in Development (WID) to Gender and Development (GAD) as well as the issue of Women's empowerment" (Abdullahi, 2014; http://www.peacebuildinginitiative.org). The desire to comprehend the power relations between Women and Men in all spheres through past development policies and program failures gave birth to the idea that development process must be "engendered", thus approaches that merely accord Women the status of "passive recipients" of development benefits gave room to programs that recognize Women as "active partners" (http://www.peacebuildinginitiative.org; Abdullahi, 2014).

In line with this paradigm shift, the need to factor the Male gender into the equation towards altering the socio-economic empowerment of Women became crucial, hence many Instruments 


\section{International Journal of Social Science and Economic Research}

ISSN: $2455-8834$

Volume: 05, Issue: 05 "May 2020"

on gender approach to peacebuilding and Women's fundamental human rights arose. Some of these Instruments include the following:

- The 1995 Platform for Action and Beijing Declaration at a Fourth World Conference on Women. This platform set out six (6) strategic objectives towards increasing "the participation of Women in conflict resolution at decision-making levels" in its section on Women in Armed Conflict (Beijing Conference, 1995).

- Goal number three (3) of the United Nations Millennium Development Goals (MDGs) in year 2000. This promotes gender equality and empowerment of Women and Girls through their inclusion in equal access to education, employment and decision-making positions. The Millennium Summit Declaration stressed the important "role of Women in the prevention and resolution of conflicts as well as peacebuilding" (UNDP, 2007:8).

- In September, 2015, the United Nations General Assembly adopted the 2030 Agenda for Sustainable Development which includes 17 Goals, with "Gender Equality as its goal number five (5). Here, achieving gender equality and Women's empowerment is central to each of the 17 Goals.

- Also at the $50^{\text {th }}$ Anniversary Solemn Declaration during the Golden Jubilee celebration of the formation of Organization of African Unity/ African Union (OAU/AU)in May 2013, African Heads of States and Governments signed the AU 2063 Agenda with seven (7) Aspirations and twenty (20) goals. Aspiration number six (6) and Goal Seventeen (17) affirms to build an "An Africa whose development is people driven, relying on the potentials offered by African people, especially the Women...." with "Full Gender Equality in all spheres of life".

- The United Nations Security Council Resolution 1325 on Women, Peace and Security (UNSCR) of $31^{\text {st }}$ October, 2000. It specifically emphasized the roles of Women in conflicts and peace. This resolution recognizes the "role of Women in conflict...not as victims, but as actors in the prevention and resolution of conflict and as equal participants in peacebuilding and decision-making" which was adjudged to be "a historical decision in favor of Women" (Anju, 2006; Leatherman, 2007:53).

- The Convention on the Elimination of all Forms of Discrimination Against Women (CEDAW) with an international legal frameworks to protect and promote gender equality (UN, 1979). It "enriches Resolution 1325” (UNIFEM, 2006).

- Also the United Nations Security Council Resolution 1820 adopted in 2008 specifically emphasized "protection of Women from sexual and gender-based violence in conflict and post-conflict situations" (UN, 2008). The Resolution 1820 "urges States to protect women from gender-based crimes through diverse peacebuilding processes (with) 


\section{International Journal of Social Science and Economic Research}

ISSN: $2455-8834$

Volume: 05, Issue: 05 "May 2020"

inclusion of women in conflict resolution and prevention.... and to increase the number of women in peacekeeping and security forces" (UN, 2008).

Most recently, the UN Security Council at its 8,514 ${ }^{\text {th }}$ Meeting of $23^{\text {rd }}$ April 2019 re-affirmed its commitment to the continuing and full implementation of Resolutions 1325 (2000); 1820 (2008); 1888 (2009); 1889 (2009); 1960 (2010); 2106 (2013); 2122 (2013) and 2242 (2015) on Women, Peace and security and relevant statements of its Presidents further emphasized that persistent barriers to their implementation will only be dismantled through dedicated commitments to Women's participation, protection and promotion of (their) human rights, as well as consistent support to building Women's engagement at all levels of decision making, by recalling the commitments of the Beijing Declaration and the Platform for Action and reaffirming the obligations of State Parties to the Convention on the Elimination of All Forms of Discrimination Against Women, urging all States that have not yet done so to consider ratifying or acceding to them. (unscr.com/en/resolution/2467).

Indeed, despite several regional instruments established to reinforce the international agreements such as the "Inter-American Convention on the Prevention, Punishment and Eradication of Violence Against Women; the Protocol to the African Charter on Human and People's Rights on the Rights of Women in Africa" (see UNPFA); Nigeria's 1999 Constitution which also accorded equal rights to both gender, though in a contradictory manner, the situation of Nigerian Women during and after conflict remains very pathetic as they still constitute the unrecognized group when it comes to the dialogue table and peace building processes (Abdullahi, 2014). Arising from the above, it is essential to examine the barriers against Women's inclusion in the process of conflict resolution for peace and sustainable development in Nigeria.

\subsection{THE BARRIERS AGAINST WOMEN'S INCLUSION IN CONFLICT RESOLUTION IN NIGERIA}

From historical narrations, different societies over the centuries have inculcated the "inferiority complex notion" which sees Woman as (the weaker sex) while Men are (the stronger sex) hence the common slogan of "it is a Man's World" (Abdullahi and Abdullahi, 2011). For instance, Aristotle was one of the earliest to assert that "Women belong with slaves and animals", cited in (Abdullahi and Dantama (2009), while Biblical narration of creation portrayed her as an "afterthought" who is "frail" (Genesis, 3.16). Given this historical antecedent of Women's oppression, no wonder the Nigerian Men have succeeded in their subtle devise to suppress Women in all spheres of human endeavours. As vividly captured by Ikonne (2005) for instance:

"Pillars and corners of the patriarchy in which the Woman is only a tenant, they have put their apparently altruistic consideration of the 
International Journal of Social Science and Economic Research

ISSN: $2455-8834$

Volume: 05, Issue: 05 "May 2020"

Woman as the weaker vessel to good use in their self-serving venture to dominate the Woman body and soul...This conception of the Woman as the weaker vessel is only a myth".

Thus, over the years, the inclusion of Women in Nigeria in the process of conflict resolution has been fraught with discrimination despite the "International and Regional Conventions and calls for the expansion of the peace process frontier to enable Women" (take active part) (Ogege, 2009). This can be gauged against the backdrop that Nigeria's conflict prone environment has defied all solutions due perhaps to lack of special concern for Women's active involvement thus making reconciliation and reconstruction very difficult. The barriers that have stood against Women's inclusion in conflict resolution in Nigeria include but not limited to the following factors:

(i). Gender Stereotyping which has used the biological analogy of Woman being the weaker vessel that must be confined to the home-front and care-giving services has created a serious barrier to Women's inclusion in conflict resolution in Nigeria. As a result of this, leadership and governance roles have remained the exclusive preserve of the Nigerian Men (the stronger vessel). The negotiating table for conflict resolution becomes the exclusive rights of the Male gender, while the Women remain behind the scene (in the Kitchen).

(ii). Socio-Cultural and Religious Barriers: Women in some parts of Nigeria have been confined and prevented from participating in public life according to the dictates of religion, tradition and culture. For instance, in the Northern part of Nigeria, some Muslims see Women's role in the home to be more crucial than taking active part in public life, let alone being allowed to partake in crucial issues such as conflict resolution dialogue table (Abdullahi, 2014).

(iii). Illiteracy: From Statistical data, more than $60 \%$ of the Nigerian Women are unlettered.

Consequently, they are found handicapped in issues of articulating and addressing the knittygritty activities that result into conflict, thus are excluded from the process of its resolution. Women's illiteracy state prevent them from accessing useful and timely information and communication, especially in the face of global information and communication technology (ICT) due to their reading and writing disabilities (Abdullahi, 2004). This scenario no doubt results to absence of trained Women negotiators and Lobbyists. According to UN Development Fund (2010), less than $10 \%$ of Negotiators are Women, while they constitute only $3 \%$ of the Peace Agreement Signatories.

(iv). Male Chauvinistic Tendencies: When gauged against the Men, Women have natural inclination to peace as a result of their biological connotation of nurturing as compared to the Male with very high propensity for belligerence and violence. Characteristically, Men resort to 
International Journal of Social Science and Economic Research

ISSN: $2455-8834$

Volume: 05, Issue: 05 "May 2020"

aggressive method of conflict resolution through physical display of macho powers, while Women resort to subtle manner of resolving their problems. This biological differences has resulted in the socio-cultural stereotyping of the Female gender as "Weak". Male chauvinism creates a serious barrier and discrimination on the Women, hence they cannot make any headway in political participation which can pave way for their inclusion in fundamental societal issues. Consequently, they get shut-out in taking crucial decisions regarding conflict resolution and its processes, whereas, they have better disposition at sustaining peace, thus their roles in conflict resolution remains fundamental.

(v). Lack of Empowerment and Access to Credit Facilities: Women do not have the means to get involved in meaningful investment ventures due to lack of collateral security to access former credit for investment purposes, hence they are poor. Thus, in a scenario where the political landscape is dominated by the Men who control the societal socio-political and economic resources, when it comes to selecting the negotiating team for conflict resolution, only those who control the ivory towers of power and resources are selected. Consequently, the Male gender dictates the tune during conflict resolution, while Women are left behind the scene to scramble for the crumbs. It is useful to quickly observe that though corruption has no gender boundary, but Nigerian Men are more prone to corrupt tendencies. Thus, when they dominate the dialogue table for conflict resolution as peace negotiators, they dictate the pace of resource sharing. The implication of this in the area of economic development of the nation is best imagined. Media evidences have shown that in most cases, resources meant to cushion the hardships of the displaced victims of conflicts usually end up in private pockets and private bank accounts.

(vi). Impoverishment and Lack of Requisite Skills: In Nigeria, the feminine dimension of poverty is glaringly obvious. Consequently, "even when they are not expressly" (constrained) by tradition, they lack the financial capacity to participate in conflict resolution processes which entails both time and financial resources (Ogege, 2009). The implication of this horrible state of existence is the fact that Women do not possess the financial wherewithal towards alleviating the plights of fellow Women affected by conflicts. Thus, due to the precarious status upon which the Nigerian Women have found themselves and from the perspective of "human poverty" or "capabilities", it is very clear that they are indeed very poor in several dimensions of capabilities, especially in terms of education and health, etc, hence their inabilities to translate their capabilities to incomes that will improve their state of well-being (Sen, 1999; Abdullahi, 2004).

Thus, it is no longer in doubt that the Nigerian Women are income deficient despite their hard work and efforts. They still remained at a disadvantaged position in the area of basic skills acquisition, literacy, employment opportunities, pressure on their available time, etc (WHO, 2002). All these variables have contributed in limiting Women's political participation in 
Nigeria, especially given Nigeria's political style of "cash" for ballot papers. Arising from the above, it is useful to observe that there are several barriers that must be tackled in order to free Nigerian Women from the shackles of Male domination in the arena of conflict resolution dialogue table towards sustainable peace and development in Nigeria. These barriers that must be broken include but not limited to the following. These are discussed in the next sub-section.

\subsection{TOWARDS BREAKING THE BARRIERS FOR WOMEN'S INCLUSION IN CONFLICT RESOLUTION FOR SUSTAINABLE PEACE AND DEVELOPMENT IN NIGERIA}

For Nigeria to be among the committee of great nations in the global arena, the need to break the barriers militating against the Nigerian Women generally and their inclusion in conflict resolution in particular has become very urgent. Some of the ways through which these barriers could be removed include:

(i). Due Process in the Appointment of Stakeholders: Over the years, Nigeria has produced a lot of highly qualified/educated Women in all fields of human endeavours.

Academic merit will no doubt encourage Women to contribute to the process of conflict resolution and peace building through due process of their inclusion. The appointment of stakeholders for conflict resolution must take cognisance of academic excellence, managerial/leadership capabilities, transparency, accountability as well as zero tolerance to gender stereotyping. This will reduce the agitations for gender equality..

(ii). Ensure Documentation of Empirical Evidences on Women's Involvement in Conflict Resolution Globally: There is need to document empirical evidences of Women's involvement in conflict prevention, peace building and resolution done in different parts of the world by sharing the information on a wide scale. This will enable the Policy Makers in situating Nigerian Women's position in conflict resolution processes. In line with this, mechanisms should be created to enable Women to have access to positions in the system of governance through their profile-raising in conflict resolution among their immediate local communities and the society as a whole.

(iii). Capacity Building and Grassroots Institution Strengthening: Nigerian Women should be provided with easy access to technical and financial assistance for capacity building towards effective participation in conflict resolution process. This will also involve grassroots institutions strengthening to enhance the role of the Women in conflict scenarios, its prevention and peace building. 
International Journal of Social Science and Economic Research

ISSN: $2455-8834$

Volume: 05, Issue: 05 "May 2020"

(iv). The Role of Philanthropic Organizations: Philanthropic organizations in Nigeria should form a coalition towards sponsoring an Educational Bill that calls for the introduction of human rights, peace and gender equality at all levels of our school curricula (Primary to Tertiary levels) with particular emphasis on Women's protection and rights. In this respect, such Bill will enable the coalition of Philanthropic Organizations to commit resources in the creation of database for Nigerian Women's networks as well as advocate for resources to be channelled towards their protection within their immediate environments, communities and the society at large.

(v). Access to the Media and Communication Technologies: Gender perspective in access to the media and communication technologies should be enhanced to ensure that Nigerian Women in the Media can exert greater influence in decision-making and public discourse on conflict resolution for peace and security. In the light of this, Mass Media awareness campaign programs should be directed at educating Women on the need for their active participation in conflict resolution for sustainable peace, security and development. In this respect, Mass Media should give emphasis to peaceful co-habitation as against sensational reportage of conflicts by providing relevant reconciliatory information.

(vi). Paradigm Shift from Agony to Organization: It is useful to observe that Nigerian Women have failed to dream, plan and strategize their roles towards a peaceful Nation, hence, their specific roles in the different components of conflict resolution such as justice, entrepreneurship, psychological recovery, security, democracy and governance have NOT been re-enforced to be a crucial agenda in their general activities. Therefore, the need to understand the trajectories of their roles in Nigeria's history, hence embark on robust self-organization into a formidable force towards making their voices heard has become an imperative, rather than taking the back seat and agonising over non-inclusion in all crucial societal issues, especially given the fact that they command $50 \%$ of the total population of the nation. Consequently, Women must and should be involved in conflict prevention, resolution and management efforts at all levels. This is occasioned by the fact that when they are not active participants, it results to a scenario whereby the views, felt-needs and interests of the better half of the population are not represented and addressed, thereby making interventions not enduring or inappropriate with the resultant consequences of the effects of war weighing more heavily on the lives of Women.

(vii). Prioritization of Women's Rights: This is about accommodating the legitimate concerns, interests and aspirations of Women, especially in the area of education, political participation and equal access to economic resources through open display of good governance and responsible leadership. In addition, Women's special concerns during conflicts like all forms of sexual violence must be addressed through Women's inclusion in conflict resolution processes. In this respect, there is need to train Women Negotiators as well as Women Lobbyists since such 


\section{International Journal of Social Science and Economic Research}

ISSN: $2455-8834$

Volume: 05, Issue: 05 "May 2020"

category of Women will play crucial roles in actualizing the essential objectives of Women's inclusion in the conflict resolution processes. Such Women Negotiators and Lobbyists will ensure that discriminatory laws or gender biased enforcement and application of existing laws are restructured through mainstreaming Women's felt-needs. They will also be able to foster the elimination of harmful social norms and practices against Women, while ensuring that structural inequalities are eliminated by addressing the root causes of violent conflicts as part of conflict prevention, resolution and peacebuilding for sustainable development.

(viii). The Need to Ensure Treaty Implementation: Despite Nigeria's signatory to several Treaties on Women's fundamental human rights, there has been very slow pace or zero implementation of the Treaties due to lack of Women in Parliaments and governance since the Male gender constitute the greatest percentage of those who make and implement policies. The need to provide official guarantee of the rights of Women by ensuring that there is effective implementation of Treaties across the three tiers of government (Federal, State and Local) cannot be overemphasized. This will go a long way in ensuring that Women's identity and visibility are maintained. In this regard, Policy Makers must respect the rule of law by ensuring that all the Treaties regarding Women's human rights are duly implemented. The role of Women Networks and Civil Society organizations are very crucial as they can make their voices heard through public enlightenment and awareness campaigns.

Arising from the above, it useful to observe that breaking the barriers militating against Women's inclusion in conflict resolution for sustainable peace and development can be actualized by implementing the above suggestions, through mainstreaming those issues in policies regarding conflict resolution and peace building processes in Nigeria.

\subsection{CONCLUSIONS}

On a general note, it is important to observe that conflicts are inevitable phenomena in any social relations, while violent conflicts can be prevented by recognizing the early warning signs which should command early action from the immediate community to the State as well as national levels, the inclusion of Women in conflict resolution process would lead to the quality of the outcomes of the agreements reached. This will no doubt enhance the chances of achieving success in the implementation exercise. Therefore, conflict resolution becomes effective if Women are included during the planning and implementation processes. For Nigerian Women to be relevant and their voices heard among the Male dominated system, a lot of efforts must be channelled towards their integration and encouragement through their inclusion in decisionmaking positions at all levels of dialogue procedures. Thus, the need for a gender mainstreaming agenda in the activities of governance in Nigeria has become fundamental, especially in the area 


\section{International Journal of Social Science and Economic Research}

ISSN: $2455-8834$

Volume: 05, Issue: 05 "May 2020"

of creating gender balance in the nomination of stakeholders for conflict resolution exercise for peace building.

It is important to conclude this paper by observing that in the life of any rational society or nation, it is imperative that during crisis moments, there is need for strategic and difficult decisions which must be taken that may or will ultimately influence the survival of the nation as well as the welfare of life of the general masses. Until very recently when the $35 \%$ affirmative action on the appointment positions for Nigerian Women became partially operational (following Nigeria's democracy), their voices over several decades have been absent in critical decisionmaking, such as conflict resolution stakeholders membership selections. While effective governance require that Women from varying requisite qualifications, backgrounds and experiences should be included in the development of policies that affects and address their feltneeds and well-being, the reverse had been the case in Nigeria. Therefore, to respond to the brutal and systemic violation of Women's rights globally and Nigerian Women in particular as a result of armed conflicts, governments must move beyond Male defined norms and value systems, i.e. a move that requires critical re-examination of gender biases by recognizing the rights of Women as human rights. The Nigerian Government must seek to end the politically and culturally constructed barriers against the Nigerian Women. Every rational government has the responsibility to stop the abuse of Women's rights within its borders as well as to end the connivance with the forces that sustain such violation. In this respect, the crucial role of both print and mass media cannot be overemphasized.

On a final note, it is useful to stress that gender equality is a fundamental human right globally. Consequently, the fulfilment of this right constitute the unique chance of actualizing most of the critical challenges facing our nation in recent times, especially the escalating socio-political, economic and security crisis. Given the United Nations 2030 and the African Union 2063 Agendas where inclusiveness is a priority, while socioeconomic development and peaceful societies are core objectives for both Agendas respectively, it is only natural that by ensuring the rights of Women generally and the Nigerian Women in particular will the society achieve shared peace for future generation. Consequently, Nigerian Women desire a nation whose sociopolitical and economic growth and development is "gender-inclusive-driven", with heavy reliance on Women's robust potentials for sustainable peace, which can lead to a prosperous nation anchored on inclusive growth and sustainable development. Therefore, Nigerian Women need support as drivers of the nation's renaissance for silencing the guns through inclusive dialogue-centred conflict prevention and resolution. The need to enhance Nigerian Women's voice and visibility in negotiation through integration at both the community, Local government, State and Federal levels has become an imperative. 
International Journal of Social Science and Economic Research

ISSN: $2455-8834$

Volume: 05, Issue: 05 "May 2020"

There must be a paradigm shift from the outdated notion of a 'Man's World' to attitudinal change and mind-sets of rekindling and strengthening the Nigerian value system of solidarity and collective prosperity that will foster the building of a nation based on best practices and superb model of sustainable peace and development for posterity. On this note we end the paper.

\section{BIBLIOGRAPHY}

Abdullahi, H. (2014), "Gender Bias and Peace building in Nigeria: Implications For Philanthropic Organizations and Sustainable Development"; Being a Paper presented at the International Conference on the Theme: "Philanthropy and Peace building: Classical Approaches and Emerging Trends", Organized by Journalists and Writers Foundation, Kimse Yok $\mathrm{Mu}$, and Istanbul Bilgi University, Istanbul, Turkey, $10^{\text {th }}-12^{\text {th }}$ April. Venue: Istanbul Bilgi University, Istanbul, Turkey.

Abdullahi, H. (2004), "A Study on Women and Poverty in Nigeria from Islamic Perspective with Special Reference to Ebira-Tao Community in Kogi State (1985-2000)", an unpublished $\mathrm{PhD}$ Thesis submitted to the Postgraduate School, Usmanu Danfodiyo University, Sokoto, Nigeria.

Abdullahi, H. and Abdullahi, Y. Z. (2011), "Gender Bias and Citizenship Rights to Political Participation in Nigeria: Challenges for Democratic Consolidation and Economic Development", in Ife Psychological Journal of Gender and Behaviour, Vol.9 (2), Nigeria.

Abdullahi, H. and Dantama, Y. U. (2009), "Gender Equity and Nigeria's Economic Reform Agenda: Challenges for National Security and Sustainable Development", a paper presented at the $2^{\text {nd }}$ National Conference, organized by the Faculty of Social and Management Sciences, Kaduna State University, on the Theme: Security and Nigeria's Development, $7^{\text {th }}-11^{\text {th }}$ December, Nigeria.

AbdulKarim, T. H. (2003), "Conflict Prevention and Post-Conflict Peace building in Nigeria: Gender Perspective", a paper presented at the National Conference on Education for Sustainable Development, College of Education, Minna, Niger State, Nigeria.

Anju, C. (2006), "Women's Intervention in the Peace Processes", Nepal Samacharpatra, August 29.

Bala, U. (2005), "Violent Ethnic Conflicts in Nigeria: Beyond Myths and Mystifications", in Analysis, Vol. 2, No. 2, Published and printed in Zaria, Nigeria, 2003. Retrieved from http://www.ceddert.com/ on $22^{\text {nd }}$ May. 


\section{International Journal of Social Science and Economic Research}

ISSN: $2455-8834$

Volume: 05, Issue: 05 "May 2020"

Benjamin, A, (2003), “The Nigeria-Biafra War Letters: A Soldier's Story”, Compiled and Edited by Abiodun A.A. Retrieved from http://www.blackscorpion.org, on $22^{\text {nd }}$ May, 2005.

Bunch, C. (199), "Transforming Human Rights from a Feminist Perspective", in Peters, J. and Woolper, A. (EDS), Women's Rights - Human Rights: International Feminist Perspectives, New York, Routledge.

Bello, A.A.; Abdullahi, H. and Olarinde M.O. (2016), "Towards Addressing the Feminine Dimension of Peace and Conflict Resolution for Sustainable Development in Nigeria; A Paper Presented At The First National Conference Organized by the Faculty of Arts a nd Islamic Studies (FAIS), Usmanu Dan Fodiyo University, Sokoto, on the Theme: "The Role Of Language, History And Religion in the Development, Integration and Security of Nigeria”. Tuesday $1^{\text {st }}-$ Thursday $3^{\text {rd }}$, March, Usmanu Danfodiyo University Auditorium, P/Site, Sokoto-Nigeria.

Dunmoye, R.A. (2014), "Pluralism and Security Challenges in Nigeria", A Keynote Address presented at the $12^{\text {th }}$ Annual National Conference of the Fulbright Alumni Association of Nigeria (FAAN), on the Theme: Pluralism, Insecurity and the State in Nigeria, at Ahmadu Bello University, Zaria, $13^{\text {th }}-16^{\text {th }}$ October.

Ikonne, C. (2005), "The Conception of Woman as the Weaker Vessel: Its Implications for Sustainable Development", in Ikonne, C., Williams, I.O. and Nwagbara, E.N.(ED), Security, Social Services and Sustainable in Nigeria, a Fulbright Alumni Association of Nigeria (FAAN) publication, University of Port Harcourt Press, Nigeria.

Leatherman, J (2003), "Sexual Violence and Armed Conflict: Complex Dynamics of ReVictimization", International Journal of Peace Studies, Vol. 12, No. 1.

Norlander, R.J. (2012), The Role of Women in Conflict Resolution (Blog), by Saybrook University, Saybrook Forum, Interdisciplinary Approaches, Monday, April, 30 ${ }^{\text {th }}$. (http//www.saybrook.edu/unbound/role-women).

Platform for Action and Beijing Declaration, Fourth World Conference on Women (Beijing, China, 1995).

Sen, A. (1999), Development as Freedom, Anchor Books. A Division of Random House, Inc, New York.

Sugh, E.F and Ikwuba, A. (2017), "Women in Mediation and Conflict Resolutions: Lessons, Challenges and Prospects for Africa", in Journal of Humanities and Social Science (IOSR-JHSS), Vol.22. Issue 1, Ver. 2 (January, pp.01-06 (www.iosrjournals.org). 
UNIFEM, 2005, Securing the Peace: Guiding the International Community Towards Women's Effective Participation Throughout Peace Processes, edited by Camille Pampell, Conaway Klara Banaszak, Anne Marie Goetz, Aina Liyambo and Maha Muna, New York: UNIFEM.

United Nations (2019), Resolution 2464 S/RES/2467: Women and Peace and Security: Sexual Violence in Conflict.

United Nations Development Fund for Women (UNIFEM), 2006, "Cedaw and Security Council Resolution 1325: A Quick Guide", New York, UNIFEM.

United Nations, 1979, "Convention on the Elimination of All Forms of Discrimination Against Women.

United Nations, 2002, Women, Peace and Security, Study Submitted by the Secretary General Pursuant to Security Council Resolution 1325, (2000), New York: United Nations.

United Nations Development Programme, 2007, Empowered and Equal: Gender Equality Strategy, New York: UNDP.

(UNDP/NPC, 1997).

World Commission on Environment and Development (WCED) (1987) (Burdthland Report), Our Common Future, Oxford University Press.

\section{Websites Visited:}

unscr.com/en/resolution/2467

https://www.thefreedictionary.com/barrier

https://www.collinsdictionary.com/dictionary/english/barrier

https://www.ec.europa.eu/knowledge4policy/publication

http://www.un.org/development/desa/disabilities/envision 